\title{
Not Just Wanna Have Fun: Teaching Listening Skills with Songs
}

\author{
Amalia Qistina Abdullah \\ English Language Department, Academy of Language Studies \\ Universiti Teknologi MARA, Negeri Sembilan \\ Kampus Kuala Pilah, Beting \\ 72000 Kuala Pilah, Negeri Sembilan, Malaysia \\ E-mail: qistina@ns.uitm.edu.my
}

Doi:10.7575/aiac.alls.v.4n.2p.96

Received: 02/04/2013

URL: http://dx.doi.org/10.7575/aiac.alls.v.4n.2p.96

Accepted: 04/06/2013

\begin{abstract}
Teaching listening skills is very challenging to ESL teachers. It involves active participation from both teachers and students to ensure the objectives of teaching listening skills can be achieved. Hence, this presentation provides interesting and exciting strategies to teach listening skills using selected songs. It is hoped that this would motivate ESL teachers to apply and adapt these strategies in their English language classrooms.
\end{abstract}

Keywords: Teaching, songs, listening skill

\section{Introduction}

The art of listening should be a major concern for both teachers and students learning ESL or EFL. While the other three language skills receive direct instructional attention, teachers frequently expect students to develop their listening capability by osmosis and without help (Mendelssohn, 1984). One of the primary causes of difficulty with English literacy among Malay learners is that English is a language that most of the Malay teenagers are not interested with. Thus, for them, learning the English language is a struggle; students tend to listen without hearing. It is not the inability to hear that causes the most persistent problem of selective deafness, but the enormous constraints that inability puts upon the learning and use of the societal language. As students are not motivated to listen to English in its spoken form, the challenge for them of developing literacy skills is much greater, in some ways, than it is for hearing nonnative English speakers.

\section{Literature Review}

Song lyrics have long been considered a part of literature. According to ancient Greek history (1982), lyric poems were defined as verses that were normally accompanied by a string instrument. Eventually, as time passed by, these poems began taking other forms such as Persian ghazals, Indian bhajans, Shakespearean sonnets and many more. What the Europeans described as a poem accompanied by music, the Chinese referred to as "Dramatic Lyrics". In an article by Maniago (2010), song lyrics are defined as "the poetry of this generation". The article also discusses the idea that songs today reflect the general rule of writing which is "the principle of showing and not telling". What Maniago (2010) refers to is the idea that song lyrics project the same reflections of a written piece and therefore falls into the same category as any other literary piece of work. In another article entitled Rock Lyrics is Poetry (Maybe), Christgau (1967) states that modern poetry today, "assumes (and sometimes eliminates) metaphoric ability, concentrating on the use of line and rhythm to approximate speech". Therefore, it can be concluded that most lyrics today, can be considered a form of modern poetry.

According to Tony Lynch, University of Edinburgh, traditionally, listening was viewed as a passive process, in which our ears were receivers into which information was poured, and all the listener had to do was passively register the message.

Today we recognize that listening is an active process, and that good listeners are just as active when listening as speakers are when speaking. This is because within the process of listening, they are successful in the analysis of the song through critical thinking thus comprehension takes place.'The single most important goal in the teaching of listening comprehension must be to give learners the experience of success"(Brown 1995: 71).

Listening can no longer be relegated to the status of an enabling skill that simply help students to speak (Nord, 1981) in the traditional, frenzied "hear it, repeat it!" "hear it, translate it!" mode so well described by Meyer (1984).

"I never know what my lecturer says after I leave the classroom. It's like she's talking Russian. I try to follow what she's saying, but she talks too fast and uses words that mean nothing to me. I don't want her to think I'm stupid...I am not stupid. I may be slow, but not stupid." 
Rushing an adult to demonstrate a new skill can lead to incapacitating anxiety, frustration, and unwillingness to perform for fear of failure and shame (Morrow, Weiner, Steinley, Young and Murray 2007)

\section{Sample of lyric analysis}

I have been experimenting on lyric analysis for almost two years now in my classes, music being the universal language tends to bridge the gap that makes the study of listening boring and even at times blurs the relevance of what they are hearing. Both teachers and listeners even by-pass that boundary called "culture". The question that I always ask my students; "What is in that song that makes it relevant for you?" Their answers are as follows:

1. Element of surprise

2. Develop their critical thinking through song analysis

3. Increases their vocabulary

4. Develop the skill to paraphrase

As a result of this initial question, I have developed a lesson plan for lyric analysis.

\section{Lesson Plan}

1. Students choose a song.

\begin{tabular}{|l|l|}
\hline & List of Songs \\
\hline 1. & "Temporary Home" by Carrie Underwood \\
\hline 2. & "Let's Wait Awhile" by Janet Jackson \\
\hline 3. & "The chosen One" by Maher Zain \\
\hline 4. & "What Do You want from Me" by Adam Lambert \\
\hline
\end{tabular}

2. Listen to the song chosen and give a brief analysis.

3. Make a comparison on the level of appreciation before and after analyzing the lyrics of the song chosen.

4. Show a sample of activity.

\begin{tabular}{|c|c|}
\hline \multicolumn{2}{|c|}{ "Temporary Home" by Carrie Underwood } \\
\hline Stanza 1 & Lyric analysis \\
\hline $\begin{array}{l}\text { Little boy, six years old a little too used to being alone. } \\
\text { Another new mom and dad, another school, } \\
\text { another house that'll never be home }\end{array}$ & $\begin{array}{l}\text { An orphan who does not fit in and his continuous } \\
\text { search to belong. }\end{array}$ \\
\hline \multicolumn{2}{|l|}{ Chorus } \\
\hline $\begin{array}{l}\text { When people ask him how he likes this place, he looks } \\
\text { up and says with a smile upon his face. This is my } \\
\text { temporary home it's not where I belong windows and } \\
\text { rooms that I'm passing through. } \\
\text { This is just a stop on the way to where I'm going. I'm } \\
\text { not afraid because I know this is my temporary home. }\end{array}$ & $\begin{array}{l}\text { A smile of sarcasm because he feels that even in his } \\
\text { search he could never find a 'home' and considers his } \\
\text { time here on earth just a passing through to a place } \\
\text { where he belongs (with his Creator). }\end{array}$ \\
\hline \multicolumn{2}{|l|}{ Stanza 2} \\
\hline $\begin{array}{l}\text { Young mom on her own, she needs a little help, got } \\
\text { nowhere to go. } \\
\text { She's looking for a job, looking for a way out } \\
\text { 'Cause a halfway house will never be a home. } \\
\text { At night she whispers to her baby girl } \\
\text { "Someday we'll find our place here in this } \\
\text { world" }\end{array}$ & $\begin{array}{l}\text { A single young mom who needs to fend for her baby } \\
\text { girl. Throughout her trials she comforts both herself } \\
\text { and her baby that sooner or later they will eventually } \\
\text { find a better life, a better place that they could call } \\
\text { home. }\end{array}$ \\
\hline \multicolumn{2}{|l|}{ Stanza 3} \\
\hline $\begin{array}{l}\text { Old man, hospital bed, the room is filled with people } \\
\text { he loves and he whispers "Don't cry for me, I'll } \\
\text { see you all someday" He looks up and says "I } \\
\text { can see God's face" }\end{array}$ & $\begin{array}{l}\text { An old man ready to face his Creator and is contented } \\
\text { with the kind of home he was in. }\end{array}$ \\
\hline
\end{tabular}


5. Discussion based on the song, "Temporary Home" by Carrie Underwood.

\begin{tabular}{|c|c|}
\hline \multicolumn{2}{|c|}{ "Temporary Home" by Carrie Underwood } \\
\hline Vocabulary & Temporary \\
\hline Main Idea & Nothing is permanent in this world \\
\hline Supporting details & $\begin{array}{l}\text { - Another new mom and dad, another school, } \\
\text { another house that'll never be home } \\
\text { - This is my temporary home it's not where I } \\
\text { belong } \\
\text { - I'm not afraid because I know this is my } \\
\text { temporary home } \\
\text { - Someday we'll find our place here in this } \\
\text { world } \\
\text { - Don't cry for me, I'll see you all someday" } \\
\text { He looks up and says "I can see God's face }\end{array}$ \\
\hline
\end{tabular}

\section{Conclusion}

Listening to their favorite music is not just wanna have fun, but rather having fun while learning.

Mastering the art of listening in English is a lifelong struggle for many tertiary students. They develop literacy differently, with acquiring literacy in English through listening various factors are considered; like language, culture, and educational background. Instructional approaches, which (a) are student-centered, (b) require meaningful use of ESL, (c) incorporate and build on the language and cultural backgrounds and actual personal issues, and (d) use creative means to teach how to listen, promise to make the educational process more meaningful, positive, and successful. The eradication of selective deafness will only be possible with the collaboration of effective teaching methods and increasing the student's motivation in learning ESL. The use of these approaches for developing the literacy skills of those who developed selective deafness needs to be carefully documented and the degree of success determined.

\section{References}

Bhajanshttp://www.dictionary.reference.com/browse/bhajans

Brown, John Russell( 1995:71)http://www.scribd.com/doc/65469673/Content-of-Thesis

Breecher, M.B. (1983) How to be a better listener and get more out of life.L.A. Times News Syndicate.

Christgau, Robert. "Rock Lyrics are Poetry (Maybe)”. Cheetah. 1967. Web. 2 June 2011.

http://www.robertchristgau.com/xg/music/lyrics-che.php

Coakley, C.J. and Wolvin, A.D. (1986) Listening in the native language. In Wing, B.H. (ed), Listening, Reading and Writing: Analysis and Application, pp.11-42. Middlebury, VT: Northeast Conference on the Teaching of Foreign Languages.

Ellis,R. (1986) Understanding Second Language Acquisition. Oxford: Oxford University Press.

Feyten, C.M. (1991) The power of listening ability: an overlooked dimension in language acquisition.

Ghazalshttp://www.en.wikipedia.org/wiki/Ghazal

Lynch,T.(2010) Study Listening $2^{\text {nd }} E d$. Cambridge: Cambridge University Press.

Maniago, Beihttp://www.articlebase.com/authors/bei-maniago/30340

Mendlsohn,D.J. (1984) There ARE strategies for listening. TEAL Occasional Papers 8, 63-76.

Meyer,R. (1984) 'Listen my children and you shall hear...” Foreign Language Annals 17, 343-344.

Modern Language Journal 75, 173-180.

Morrow, D.G., Weiner, M., Steinley, D., Young, J., \& Murray, M. (2007). Patients' health literacy and experience with instructions: Influence preferences for heart failure medication instructions. Journal of Aging and Health, 19, 575-593.

Nord, J.R. (1981) Three steps to listening fluency: a beginning. In Winitz, H. (ed.), The Comprehension Approach to Foreign Language Instruction. Rowley, MA: Newbury House. 